\title{
Manajemen Tekanan Darah Setelah Cedera Sistem Saraf Pusat
}

\author{
Radian Ahmad Halimi, Dewi Yulianti Bisri \\ Departemen Anestesiologi dan Terapi Intensif \\ Fakultas Kedokteran Universitas Padjadjaran RS. Dr. Hasan Sadikin Bandung
}

\begin{abstract}
Abstrak
Hipertensi yang tidak terkontrol sering dijumpai setelah cedera otak. Mekanisme mengenai respon fisiologis dan patologis ini berhubungan dengan respons autoregulasi yang bertujuan untuk mempertahankan aliran darah otak di area yang terkena cedera. Respons hipertensi awal mungkin akan mempercepat/memicu cedera lebih lanjut. Sebaliknya, penurunan tekanan darah secara agresifjustru berhubungan dengan kejadian iskemik. Meskipun tekanan darah sudah jelas berperan sebagai modulator dalam cedera otak akut, berbagai penelitian masih menunjukkan kontroversi dan belum ada data-data berkualitas terkait demografis, manajemen optimal terhadap tekanan darah tinggi dan hasil akhir pada pasien yang mengalami cedera otak akut. Kondisi hipertensi pascaoperasi merupakan komplikasi pascabedah yang sering terjadi pada populasi pasien bedah saraf, Hipertensi pascabedah kraniotomi memiliki angka kejadian paling tinggi dibandingkan dengan prosedur pembedahan lainnya. Hipertensi pascabedah atau saat pemulihan anestesi dapat menyebabkan terjadinya perdarahan dan edema intrakranial. Peningkatan tekanan darah sistemik berkorelasi dengan kondisi perdarahan ulang intracranial, gangguan cerebrovaskular, dan infark miokard pada pascabedah kraniotomi, yang nantinya akan menyebabkan terjadinya peningkatan angka morbiditas dan mortalitas. Peningkatan atau penurunan tekanan darah yang ekstrem pada kondisi cedera otak atau cedera tulang belakang dapat menyebabkan terjadinya suatu cedera sekunder. Hubungan kausal antara tekanan darah ekstrem dan cedera otak masih diperdebatkan. Deteksi kelainan autoregulasi yang terjadi setelah cedera otak dan tulang belakang perlu dilakukan sebagai acuan untuk melakukan terapi kontrol tekanan darah yang optimal, dan menghindari komplikasi akibat penurunan atau peningkatan tekanan darah yang berlebihan.
\end{abstract}

Kata kunci: Autoregulasi, hipertensi, obat anti hipertensi

JNI 2019;8 (2): 132-43

\section{Blood Pressure Management After Central Nervous System Injury}

\begin{abstract}
Uncontrolled hypertension is often encountered after brain injury. This mechanism related to physiologic and pathologic response are related to autoregulatory responses aimed at preserving the cerebral blood flow in injured areas. The initial hypertensive response may precipitate further injury. Conversely, aggresive blood pressure reduction may be associated with ischemia. Despite the clear role of blood pressure as a modulator of acute brain injury, there is considerable controversy and a lack of high-quality data regarding the demographics, outcomes, and optimal management of high blood pressure in acute brain-injured patients. The condition of postoperative hypertension is a postoperative complication that often occurs in the population of neurosurgical patients. Postoperative hypertension craniotomy has the highest incidence compared to other surgical procedures. Postoperative hypertension on recovery of anesthesia can cause intracranial bleeding and edema. Increased systemic blood pressure correlates with intracranial rebleeding conditions, cerebrovascular disorders, and myocardial infarction at the postoperative craniotomy, which in turn will cause an increase in morbidity and mortality. Extreme blood pressure increase or decrease in a brain injury or spinal cord injury can cause a secondary injury. The causal relationship between extreme blood pressure and brain injury is debatable. Detection of autoregulation abnormalities that occur after brain and spinal cord injury need to be done as a reference for optimal blood pressure control therapy, and avoid complications due to decreased or increased excessive blood pressure.
\end{abstract}

Key words: Antihypertension drugs, autoregulation, hypertension.

JNI 2019;8 (4): 132-43 


\section{Pendahuluan}

Cedera sistem saraf pusat (SSP) berupa stroke iskemik akut, perdarahan intraserebral, perdarahan subaraknoid, cedera otak traumatik dan bentuk cedera lainnya dapat menjadi faktor presipitasi terhadap terjadinya kondisi hipertensi krisis dan berperan pada terjadinya gagal organ akhir. Peningkatan tekanan darah yang terlalu ekstrem perioperatif akan meningkatkan mortalitas dan morbiditas pasien-pasien cedera SSP. ${ }^{1}$ Kondisi hipertensi pascaoperasi merupakan komplikasi pascabedah yang sering terjadi pada populasi pasien bedah saraf, Hipertensi pascabedah kraniotomi memiliki angka kejadian paling tinggi dibandingkan dengan prosedur pembedahan lainnya. Hipertensi pascabedah atau saat pemulihan anestesi dapat menyebabkan terjadinya perdarahan dan edema intrakranial. Peningkatan tekanan darah sistemik berkorelasi dengan kondisi perdarahan ulang intrakranial pada pascabedah kraniotomi. ${ }^{2,3}$

Regulasi tekanan darah secara ketat di ruang neuroICU perlu dilakukan pada pasien dengan cedera sistem saraf pusat secara intermiten atau kontinyu menggunakan terapi antihipertensi intravena. Namun, hingga saat ini belum banyak studi atau data yang mengevaluasi efek jangka pendek dan jangka panjang dari tatalaksana hipertensi menggunakan regimen antihipertensi tertentu, khususnya pada kondisi hipertensi krisis. Data-data objektif terkait demografik, hasil luaran (outcome), dan tatalaksana hipertensi yang optimal pada pasien-pasien dengan cedera otak akut, hingga saat ini masih kontroversial. ${ }^{1}$ Saat menangani pasien dengan hipertensi dengan gangguan sistem saraf pusat (co:gangguan neovaskuler, cedera kepala berat, keganasan) terdapat 2 hal yang perlu dipertimbangkan dan dilakukan secara seimbang. Hal pertama adalah peningkatan tekanan darah secara akut akan menyebabkan terjadinya kerusakan pada pembuluh darah mikro di otak yang menyebabkan terjadinya kondsi perdarahan otak atau tempat lainnya. Pertimbangan kedua adalah penurunan tekanan darah dapat menyebabkan jaringan di tubuh (terutama otak) tidak mendapat perfusi yang layak sehingga menyebabkan terjadinya kondisi iskemia. Faktor yang perlu dipertimbangkan saat kita akan melakukan regulasi terhadap tekanan darah diantaranya adalah; (1) Jenis kegawatan gangguan sistem saraf pusat (neovaskular, trauma kepala, keganasan, dll) (2) Derajat berat hipertensi, (3) Riwayat tekanan darah pasien sehari-hari, (4) Kondisi autoregulasi pasien. ${ }^{4}$ Peningkatan tekanan darah $(>20 \%)$ saat periode intraoperasi dipertimbangkan sebagai suatu kondisi hipertensi emergensi. Hipertensi pascabedah (peningkatan tekanan darah sistolik (systolic blood pressurel SBP) $\geq 190 \mathrm{mmHg}$ dan/atau tekanan darah diastolik (diastolic blood pressure/DBP) $\geq 100$ $\mathrm{mmHg}$ pada dua kali pemeriksaan secara berturut-turut dapat meningkatkan resiko sequele pada pasien kardiak maupun nonkardiak.

Hipertensi dan krisis hipertensi merupakan komplikasi yang sering terjadi pada periode pascabedah dan memiliki korelasi dengan meningkatnya tonus simpatis dan resistensi pembuluh darah. Hipertensi pascabedah biasanya terjadi dalam 10-20 menit pascabedah, dan dapat bertahan hingga 4 jam. Apabila kondisi hipertensi pascabedah tersebut tidak segera diatasi maka akan meningkatkan resiko untuk terjadinya

Tabel 1. Penyebab Hipertensi Saat Fase Pemulihan Anestesi $^{2}$

\begin{tabular}{l}
\hline Penyebab Hipertensi Saat Fase Pemulihan Anestesi \\
\hline Nyeri \\
Hipothermia \\
Hipo-osmolaritas \\
Anemia \\
Hipercarbia dan hipoksia \\
Emosi kegembiraan saat bangun \\
Pelepasan katekolamin atau stimulasi simpatis \\
Manipulasi di otak \\
Dilakukan pemberian obat anestetik lokal yang \\
mengandung adrenalin
\end{tabular}

perdarahan, gangguan cerebrovaskular, dan infark miokard. ${ }^{5}$

\section{Epidemiologi}

Studi mengenai tatalaksana hipertensi akut 


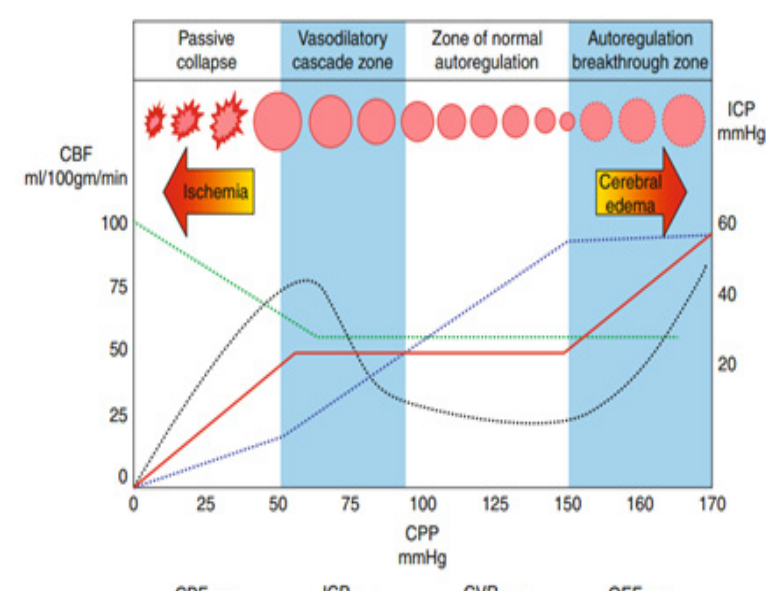

CBF - ICP $\quad$ CVR -....... OEF

Gambar 1. Autoregulasi serebrovaskular dan hubungan kegagalannya dengan berbagai determinan 1

menyatakan bahwa 30\% dari 1566 pasien yang masuk Unit Gawat Darurat (UGD) karena hipertensi akut diikuti oleh cedera SSP. Angka mortalitas pasien dengan cedera SSP 4 kali lipat lebih tinggi dibandingkan dengan pasien hipertensi tanpa cedera SSP. ${ }^{1}$ Berdasarkan beberapa penelitian didapatkan bahwa angka kejadian hipertensi perioperatif berkisar antara 54-91\%. Angka kejadian hipertensi pascabedah kraniotomi adalah 57\%. Suatu penelitian retrospektif kasus kontrol yang mengevaluasi hubungan antara peningkatan tekanan darah saat pemulihan anestesi dengan kejadian perdarahan intrakranial, mendapatkan bahwa dari keseluruhan pasien yang mengalami perdarahan intrakranial sebanyak $62 \%$ memiliki komorbid hipertensi sebelumnya, dan 34\% tidak memiliki riwayat hipertensi sebelumnya. ${ }^{6}$ Suatu penelitian prospektif yang membandingkan antara komplikasi pascabedah kraniotomi elektif dengan emergensi didapatkan bahwa angka kejadian hipertensi pada pascabedah kraniotomi elektif adalah 74\%, dan hipertensi pada pascabedah kraniotomi emergensi adalah $84 \%$. $^{7}$ Berdasarkan suatu literatur menyatakan bahwa angka kejadian hipertensi krisis pada periode pascabedah telah dilaporkan antara 4 hingga $35 \%$ pasien. $^{5}$

\section{Mekanisme Saraf dalam Mengontrol Tekanan Darah}

Otak berperan penting dalam menjaga menjaga stabilitas tekanan darah melalui berbagai komponen seperti refleks baroreseptor, pusatpusat pressor dan depressor batang otak, dan interaksi antara pressor bulbospinalis dengan medullary depressor pathways. Jaringan neuronal (jaringan otak) memiliki kebutuhan metabolik oksigen yang tinggi, sehingga membutuhkan volume aliran darah yang tinggi secara berkesinambungan. Normalnya rata-rata jumlah aliran darah yang menuju korteks otak (cerebral blood flow/CBF) adalah $50 \mathrm{ml}$ aliran darah/100 gram jaringan otak/menit (ml/100gr/menit). Saat CBF kurang dari $20 \mathrm{ml} / 100 \mathrm{gr} / \mathrm{menit}$, membran sel neuronal akan terganggu, dan hasil akhirnya adalah terjadinya kondisi disfungsi neurologis. Meskipun telah terjadi gangguan, apabila CBF dapat dikembalikan ke nilai normal, jaringan neuronal tersebut mayoritas dapat diselamatkan. Saat CBF turun hingga dibawah $10 \mathrm{ml} / 100 \mathrm{gr} /$ menit, kerusakan jaringan neuronal akan menjadi ireversibel, dan bila tidak ada aliran sama sekali, makan dalam hitungan menit akan terjadinya kematian jaringan neuronal. ${ }^{1,4}$

Saat terjadi cedera neurologis akut, strukturstruktur tersebut akan teraktivasi/terganggu melalui stimulasi neurohormonal untuk mencegah kerusakan sel-sel lebih lanjut. Cedera neurologis akut juga mempengaruhi mekanisme perifer tubuh yang mengatur dinamika tekanan darah. Faktor yang paling sering terpengaruh yakni resistensi vaskuler sistemik. ${ }^{1}$ Otak menjaga kestabilan aliran darah ke otak (CBF) melalui 2 faktor, yakni tekanan perfusi otak (cerebral perfusion pressure/CPP) dan mekanisme autoregulasi otak. Cerebral perfusion pressure merupakan hasil pengurangan mean arterial pressure (MAP) dengan TIK. Apabila terjadi perubahan pada CPP, mekanisme autoregulasi akan bekerja untuk menjaga nilai CPP diantara 50-150 mmHg melalui modifikasi neurogenik dan miogenik pada arteriol prekapiler. ${ }^{1,4}$

Mekanisme autoregulasi akan bergeser ke kanan pada pasien yang memiliki komorbid hipertensi sebelumnya. Apabila nilai MAP dibawah batas autoregulasi maka akan terjadi kondisi iskemia, dan bila nilai MAP diatas batas autoregulasi maka aliran darah ke otak akan meningkat dan 


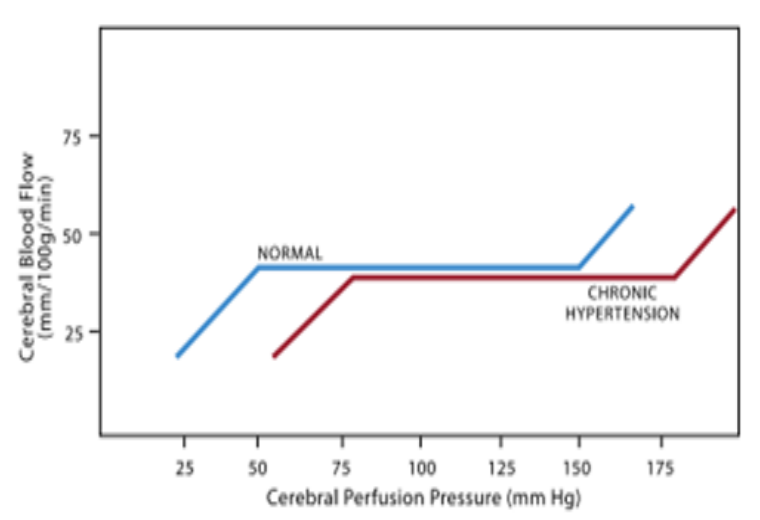

Gambar 2. Mekanisme Autoregulasi Otak ${ }^{4}$

menyebabkan terjadinya peningkatan TIK dan edema vasogenic. ${ }^{1,4}$ Gangguan neurologis akut (trauma, keganasan, vasospasme) dapat mengganggu mekanisme autoregulasi tersebut, sehingga setiap terjadi peningkatan tekanan darah akan diikuti dengan peningkatan $\mathrm{CBF}$, setiap terjadi penurunan tekanan darah akan diikuti oleh penurunan $\mathrm{CBF}$, sehingga $\mathrm{CPP}$ akan terganggu dan mengakibatkan kegagalan hemodinamik serebral., ${ }^{1,4}$ Kegagalan hemodinamik serebral tahap 1 menunjukkan kondisi autoregulasi dan rekruitmen kolateral mampu mempertahankan CBF pada kisaran normal (sekitar 50ml/100g/ menit).

Sementara itu, kegagalan hemodinamik serebral tahap 2 merupakan kondisi dimana hubungan CBF dan aktivitas metabolik terganggu saat terjadi iskemia moderat sehingga metabolisme dipertahankan dengan meningkatkan fraksi ekstraksi oksigen dari darah. Apabila 2 tahap mekanisme tersebut terjadi terus-menerus, kegagalan hemodinamik serebral akan nyata terjadi. ${ }^{1}$ Lesi otak (tumor, perdarahan, edema otak) akan menyebabkan terjadinya peningkatan TIK. Seriap kenaikan TIK akan diikuti dengan penurunan CPP apabila konstanta MAP tidak berubah, namun tubuh memiliki suatu mekanisme kompensasi untuk mempertahankan CPP agar mencegah terjadinya kondisi iskemia otak dengan meningkatkan MAP (trias cushing). Kondisi penurunan MAP akan meningkatkan angka morbiditas dan mortalitas pada pasien dengan TIK yang tinggi. Autoregulasi akan mendorong munculnya respon vasodilatasi yang justru memperburuk situasi. Dibawah batas minimum autoregulasi, dominan terjadi kerusakan iskemik dan kolaps pembuluh darah. Sementara apabila melewati batas maksimal autoregulasi, timbul peningkatan volume dan tekanan intravaskuler, cedera hipoperfusi dan edema vasogenik. ${ }^{1}$

\section{Klasifikasi Krisis Hipertensi}

Berdasarkan klasifikasi yang dikeluarkan oleh Joint National Committee (JNC) mendefinisikan kondisi krisis hipertensi dengan kondisi terjadinya peningkatan SBP $>179 \mathrm{mmHg}$ atau $\mathrm{DBP}>109$ mmHg, kemudian JNC membagi kondisi krisis hipertensi menjadi dua klasifikasi berdasarkan adanya target organ akibat hipertensi tersebut, yakni hipertensi urgensi dan emergensi. ${ }^{8}$

Hipertensiberat tanpa diikuti oleh kerusakan organ vital secara akut dan progresif diklasifikasikan sebagai hipertensi urgensi. Pasien dengan hipertensi urgensi sebaiknya diberikan obat antihipertensi oral dalam waktu 24 jam hingga 48 jam,dan dilakukan observasi ketat tanda vital baik secara rawat jalan maupun di rumah sakit. ${ }^{1,8,9}$

Hipertensi emergensi merupakan peningkatan tekanan darah yang menyebabkan terjadinya kondisi kerusakan organ secara progresif yang mencakup organ-organ seperti otak, jantung, ginjal dan retina. Kondisi hipertensi emergensi diantaranya meliputi kondisi hipertensi ensefalopati, hipertensi dengan kondisi dilatasi ventrikel kiri akut dengan infark miokard akut atau angina unstable, diseksi aorta, perdarahan subaraknoid (subarachnoid haemorrhagel $\mathrm{SAH}$ ), stroke iskemik, dan preeklampsia berat atau eklampsia. Kasus-kasus kegawatdaruratan hipertensi pada pasien neurologis, kelainan atau kerusakan otak dapat menjadi sebab (mekanisme kompensasi) maupun akibat dari peningkatan tekanan darah. Obat anti hipertensi intravena sebaiknya diberikan dalam 1 jam dari awal kejadian kegawatdaruratan hipertensi tersebut. ${ }^{1,9}$

\section{Pemilihan Obat Antihipertensi}

Manajemen krisis hipertensi menggunakan obat antihipertensi intravena terbagi menjadi beberapa 
Tabel 2. Nama Obat Berdasarkan Golongan Obat Antihipertensi

\begin{tabular}{ll}
\hline $\begin{array}{l}\text { Golongan Obat } \\
\text { Antihipertensi }\end{array}$ & $\begin{array}{l}\text { Nama Obat } \\
\text { Antihipertensi }\end{array}$ \\
\hline Vasodilator Arterial & $\begin{array}{l}\text { Hidralazin, } \\
\text { Fenoldopam, } \\
\text { Nikardipin, Enalapril } \\
\text { Nitrogliserin }\end{array}$ \\
Vasodilator Vena & Natrium Nitroprusida \\
Gabungan Vasodilator & \\
Arteri dan Vena & \\
Kronotropik Inotropik & Labetalol \\
Negatif dengan Efek & \\
Vasodilator & \\
Kronotropik Inotropik & Esmolol \\
Negatif tanpa efek & \\
Vasodilator & \\
$\alpha-2$ adrenergic receptor & Clonidine, \\
agonis & Dexmedetomidine \\
$\alpha$ adrenergic receptor & Fentolamine \\
blocker & \\
\hline
\end{tabular}

golongan berdasarkan mekanisme kerjanya, diantaranya adalah golongan vasodilator arterial, vasodilator vena, gabungan antara vasodilator arterial dan vena, agen inotropik dan chronotropik negatif dengan efek vasodilator maupun tanpa vasodilator, dan reseptor $\alpha$-adrenergik blocker. ${ }^{1}$ Labetalol intravena secara intermiten merupakan obat antihipertensi yang paling sering dipilih untuk terapi inisial pada pasien stroke dengan hipertensi berat yang akut (50\%), diikuti oleh nicardipine $(15 \%)$, hydralazine $(15 \%)$, dan sodium nitroprusside (13\%).

Nicardipine merupakan obat antihipertensi yang lebih sering digunakan untuk terapi inisial pada pasien stroke perdarahan akut dibandingkan dengan pasien stroke iskemik akut. ${ }^{1}$ Berdasarkan suatu literatur menyatakan bahwa obat antihipertensi golongan calcium channel blocker (CCB) dan ACE-inhibitor (ARB) merupakan terapi inisialyang disarankan untuk menatalaksana pasien dengan gangguan neurologis. Pemberian furosemide dan hydrochlorothiazide biasanya dihindari karena dapat menyebabkan kondisi hiponatremia. Hydralazine juga dihindari karena memiliki efek yang kompleks terhadap otak, karena dapat meningkatkan TIK dan CBF. ${ }^{10}$
Obat yang digunakan untuk menurunkan tekanan darah pada pasien dengan gangguan neurologis sebaiknya dipilih obat yang mudah dikendalikan agar tidak menurunkan tekanan darah terlalu signifikan, karena penurunan tekanan darah yang signifikan pada pasien dengan gangguan neurologis dapat menyebabkan terjadinya kondisi iskemia otak. Labetalol intravena merupakan obat yang menjadi pilihan untuk menurunkan tekanan darah pada fase akut, karena obat ini memiliki onset dan durasi yang cepat sehingga dapat dilakukan penurunan tekanan darah secara cepat dan aman untuk mencapai tekanan darah yang diinginkan. Terapi lini pertama lainnya yang biasa digunakan adalah nicardipine, dan pada beberapa kasus dapat digunakan hydralazine atau enalaprilat. Berdasarkan suatu literatur menyatakan bahwa saat ini hydralazine tidak lagi dijadikan terapi lini pertama untuk penanganan hipertensi pada pasien dengan gangguan neurologis, karena efeknya yang tidak dapat diprediksi terhadap TIK dan CBF.

Pemilihan obat antihipertensi sebaiknya didasari oleh pertimbangan biaya dan pengetahuan klinisi terhadap obat yang digunakan. ${ }^{11,12}$ Terapi nitroprusside intravena sebaiknya digunakan sebagai terapi lini kedua untuk penanganan hipertensi, karena secara teori dapat meningkatkan TIK dan mempengaruhi fungsi platelet. Formulasi nifedipine dengan kerja cepat, sebaiknya dihindari karena dapat menyebabkan terjadinya penurunan tekanan darah yang berkepanjangan dan berat, sehingga berdasarkan beberapa penelitian mendapatkan bahwa penggunaan nifedipine dapat meningkatkan angka kejadian stroke iskemik pada populasi pasien geriatrik dengan gangguan neurologis. ${ }^{11}$

\section{Penanganan Tekanan Darah pada Kegawatdaruratan Neurologis Khusus Perdarahan Intraserebral}

Respons hipertensi akut dijumpai pada $46 \%-$ $75 \%$ pasien dengan perdarahan intraserebral. Hal ini menunjukkan bahwa sebanyak 16.650 dari 35.000 pasien dengan ICH setiap tahunnya memiliki komorbiditas hipertensi sebelumnya. Kondisi peningkatan SBP inisial diasosiasikan dengan meluasnya kondisi perdarahan otak, 
meningkatnya angka mortalitas, dan pembentukan edema otak perihematoma pada pasien dengan $\mathrm{ICH}$, meskipun mekanismenya masih belum jelas. Suatu studi mendapatkan suatu hubungan yang inkonsisten antara peningkatan SBP dengan ekspansi hematoma (menurunkan SBP akan menurunkan kemungkinan terjadinya ekspansi hematoma).

Berdasarkan beberapa penelitian yang telah dilakukan mendapatkan bahwa penurunan SBP dapat ditoleransi karena akan menurunkan metabolisme otak dan menjaga autoregulasi pada daerah perihematoma. American Heart Association Stroke merekomendasikan untuk menjaga $\mathrm{SBP}<180$ pada fase akut menggunakan obat antihipertensi intravena yang memiliki durasi obat yang pendek. Panduan tatalaksana ini mempertimbangkan untuk melakukan penurunan tekanan darah SBP lebih agresif pada pasien yang tidak menunjukkan tanda-tanda peningkatan TIK, atau memiliki komorbiditas hipertensi kronis sebelumnya. Peningkatan tekanan darah biasanya terjadi dan paling sering ditemukan pada pasien dengan perdarahan intraserebral akut. Hal tersebut disebabkan oleh peningkatan regulasi sistem saraf simpatis, aksis renin-angiotensin dan aksis pituitari-adrenal. Kondisi tersebut dapat meningkatkan risiko perburukan kerusakan otak hingga terjadinya kematian. Berdasarkan suatu studi dan literatur, mendapatkan bahwa pasien dengan kondisi hipotensi dan hipertensi pada pasien ICH akan meningkatkan resiko penurunan fungsi neurologis, kematian, atau kondisi vegetatif. ${ }^{1,13,14}$

Secara teoritis, kondisi hipertensi yang tidak terkontrol dapat mengkontribusi untuk terjadinya ekspansi akut kondisi hematoma pada 3-4 jam pertama dari onset dan pada fase selanjutnya dapat memperberat kondisi edema perihematomal dan TIK, keduanya dapat mempengaruhi hasil luaran setelah $\mathrm{ICH}$. Besarnya volume hematoma merupakan faktor utama yang mempengaruhi angka mortalitas setelah $\mathrm{ICH}$, dan perkembangan volume hematoma secara dini secara inkonsisten diasosiasikan dengan hasil luaran yang buruk. Kondisi meluasnya hematoma dapat diakibatkan oleh perdarahan yang persisten atau perdarahan ulang akibat robekan pada arteriolar. Suatu studi membuktikan bahwa perkembangan hematoma akibat perdarahan dapat menyebabkan terjadinya kondisi iskemik penumbra pada daerah sekitar hematoma. ${ }^{1}$ Berdasarkan beberapa data pada penelitian didapatkan bahwa SBP yang tinggi merupakan faktor resiko utama terhadap kejadian $\mathrm{ICH}$, dan variabilitas SBP pada pasien ICH memberikan hasil luaran yang buruk (angka mortalitas, morbiditas, dan fungsi neurologis). ${ }^{15}$

Penurunan tekanan darah secara agresif pada pasien dengan gangguan autoregulasi dapat menyebabkan terjadinya kondisi iskemia pada daerah jaringan perihematomal, sedangkan pada pasien dengan fungsi autoregulasi yang intak dapat mengakibatkan terjadinya refleks vasodilatasi dan terjadi peningkatan TIK. ${ }^{1}$ Studi intensive blood pressure reduction in acute cerebral haemorrhage trial (INTERACT) mengevaluasi 404 pasien dengan ICH dan peningkatan SBP $(\geq 150 \mathrm{mmHg}$ dan $<220 \mathrm{mmHg}$ ) yang diberikan dalam 6 jam onset dengan target penurunan $\mathrm{SBP}<140 \mathrm{mmHg}$ (regulasi intensif) atau menggunakan panduan tatalaksana American Stroke Association dengan target SBP $<180 \mathrm{mmHg}$, menggunakan obat antihipertensi yang tersedia (tidak spesifik). Hasilnya menunjukkan penurunan kejadian meluasnya volume hematoma dari ukuran semula pada setelah 24 jam. Berdasarkan penelitian ini juga didapatkan bahwa tidak didapatkan penurunan fungsi neurologis atau efek samping lainnya akibat penurunan tekanan darah secara intensif. ${ }^{13}$ Dua penelitian besar lainnya mendapatkan bahwa penurunan $\mathrm{SBP}<140 \mathrm{mmHg}$ merupakan tindakan yang aman digunakan tanpa menimbulkan efek samping yang bermakna, sehingga penurunan $\mathrm{SBP}<140 \mathrm{mmHg}$ disarankan sebagai panduan tatalaksana pasien dengan $\mathrm{ICH} .{ }^{15}$

Studi antihypertensive treatment of acute cerebral haemorrhage (ATACH) juga memperkuat keamanan dalam melakukan penurunan tekanan darah secara cepat pada pasien ICH. Studi ini melakukan eskalasi dosis menggunakan nikardipin intravena untuk menurunkan tekanan darah pada 80 pasien dengan $\mathrm{ICH}$, dengan target SBP $<140 \mathrm{mmHg}$. Berdasarkan penelitian ini tidak didapatkan perburukan fungsi neurologis 
dan hasil luaran. Studi INTERACT dan ATACH menunjukkan bahwa penurunan tekanan darah secara cepat dan intensif secara klinis aman untuk dilakukan, namun kedua penelitian ini tidak melihat hasil luaran jangka panjang. ${ }^{1}$

American Heart Association (AHA) menyatakan bahwa SBP harus dijaga pada nilai $<180 \mathrm{mmHg}$ dan MAP $<130 \mathrm{mmHg}$ dengan pemberian obat antihipertensi melalui infus secara kontinyu selama fase akut pada pasien dengan ICH. Pasien yang memiliki volume hematoma yang lebih besar $(>30 \mathrm{cc})$ dengan resiko hipertensi intrakranial, monitoring TIK perlu dillakukan untuk menjaga CPP $>60 \mathrm{mmHg}$. Penelitian sebelumnya yang dilakukan pada 18 pasien ICH dengan kondisi koma, menggunakan monitoring multimodal menunjukkan bahwa $\mathrm{CPP}>80 \mathrm{mmHg}$ diasosiasikan dengan penurunan risiko hipoksia jaringan otak yang berkaitan erat dengan risiko kematian pasien. Obat-obatan antihipertensi yang direkomendasikan yakni golongan beta blockers dan calcium channel blockers.

Penggunaan nitroprusside memiliki angka kejadian komplikasi medikal yang lebih tinggi, dan dapat mengeksaserbasi kondisi edema otak dan TIK. Waktu untuk dilakukannya konversi dari intravena menjadi terapi oral dapat dimulai antara 24 hingga 72 jam, selama kondisi pasien telah stabil. ${ }^{1}$ Berdasarkan panduan tatalaksana yang dikeluarkan oleh European Stroke Organisation (ESO) menyatakan bahwa pada ICH spontan fase akut, penurunan SBP secara agresif dengan target SBP $<140 \mathrm{mmHg}$ dalam waktu kurang dari 1 jam merupakan teknik yang aman digunakan, dan memberikan hasil yang lebih baik dibandingkan terget $\mathrm{SBP}<180 \mathrm{mmHg}$. Berdasarkan panduan tatalaksana ini menyatakan bahwa tidak ada agen antihipertensi spesifik yang direkomendasikan untuk menurunkan tekanan darah. ${ }^{14} \quad$ Berdasarkan suatu studi mendapatkan bahwa angka kejadian hipertensi persisten pada pasien ICH dengan hipertensi adalah $31,6 \%$ pasien. Sekitar $29,2 \%$ pasien pada penelitian ini membutuhkan 5 atau lebih obat antihipertensi saat berada di ruang neuroICU. Kondisi hipertensi persisten secara independen dipengaruhi oleh body mass index (BMI) yang tinggi dan proteinuria. Body mass index yang tinggi merupakan faktor resiko hipertensi resisten, sedangkan proteinuria merupakan akibat kerusakan organ karena hipertensi kronis. ${ }^{15}$

\section{Perdarahan Subaraknoid}

Perdarahan subaraknoid merupakan tipe stroke yang memiliki angka mortalitas dan morbiditas yang tinggi, serta menimbulkan beban ekonomi yang tinggi untuk pasien karena berhubungan dengan akibat langsung dari perdarahan yang terjadi dan kondisi perdarahan ulang aneurisma. Suatu kondisi SAH akibat pecahnya aneurisma berpotensi untuk terjadi perdarahan yang berulang. Faktor yang mempengaruhi angka kejadian perdarahan ulang SAH pada aneurisma adalah besarnya ukuran aneurisma tersebut dan kondisi hipertensi yang tidak terkontrol. Namun, hipotesis mengenai hipertensi yang tidak terkontrol meningkatkan risiko perdarahan ulang hanya didukung oleh sedikit bukti penelitian. Terapi intervensi utama pada penatalaksanaan pasien dengan SAH aneurisma adalah manipulasi terhadap tekanan darah menggunakan obat antihipertensi (kondisi hipertensi) dan vasoaktif (kondisi hipotensi). ${ }^{1,16,17}$

Agen antihipertensi intravena yang dapat dititrasi (co: nikardipin) merupakan obat antihipertensi yang sering digunakan untuk menangani kondisi hipertensi ekstrim, dan target penurunan tekanan darah dilakukan secara spesifik (individualisasi) bergantung pada usia, kondisi jantung, riwayat tekanan darah sehari-hari, dan besarnya ukuran aneurisma. Kondisi hipotensi juga dihindari karena dapat menyebabkan terjadinya oligemia akibat terganggunya CPP. ${ }^{16}$

Sebagian besar fasilitas kesehatan melakukan kontrol aktif tekanan darah untuk menjaga SBP $\leq 160 \mathrm{mmHg}$ sebelum pembedahan terbuka atau tatalaksana endovaskular aneurisma yang pecah. Studi terkini menunjukkan korelasi linier dari $\mathrm{SBP} \geq 160 \mathrm{mmHg}$ dengan re-bleeding dini. Selain itu, tekanan darah ekstrim (MAP $>130$ atau $<70 \mathrm{mmHg}$ ) saat masuk rumah sakit berkaitan dengan hasil luaran yang buruk pada pasien perdarahan subaraknoid. ${ }^{1}$ Beberapa ahli menyatakan bahwa kontrol terhadap tekanan 
darah pada pasien dengan SAH sebaiknya dilakukan apabila didapatkan nilai MAP >140 $\mathrm{mmHg}$, namun ahli-ahli lainnya menyarankan agar menjaga tekanan SBP $\leq 120 \mathrm{mmHg}$ hingga $\leq 160 \mathrm{mmHg}$. Berdasarkan studi INTERACT-2 menyatakan bahwa penurunan tekanan darah $\mathrm{SBP}<140 \mathrm{mmHg}$ memberikan tingkat keamanan dan hasil yang lebih baik dibandingkan dengan target SBP $<180 \mathrm{mmHg} .{ }^{16}$ Suatu penelitian yang dilakukan oleh the intracerebral haemorrhage acutely decreasing arterial pressure trail (ICHADAPT) membandingkan antara penurunan tekanan darah dengan target $\mathrm{SBP}<150 \mathrm{mmHg}$ dengan target SBP $<180 \mathrm{mmHg}$, didapatkan bahwa tidak ada perbedaan CBF antara kedua kelompok berdasarkan pemeriksaan perfusi dengan computed tomography (CT). ${ }^{16}$

Saat ini target penurunan tekanan darah dan pemilihan obat antihipertensi masih bervariasi pada berbagai fasilitas kesehatan. Panduan AHA menyatakan bahwa banyaknya variasi target tekanan darah minimal tersebut diakibatkan oleh kurangnya data definitif khususnya terkait terapi dengan obat antihipertensi, dimana terapi antihipertensi secara tunggal tidak direkomendasikan untuk mencegah re-bleeding, namun biasanya dikombinasikan dengan monitored bed rest. Penatalaksanaan kondisi peningkatan tekanan darah sebaiknya dilakukan pemasangan kateter arteri (arterial line), dan obat antihipertensi parenteral yang digunakan memiliki sifat durasi obat yang pendek, mudah dititrasi, efek samping yang minimal terhadap fungsi jantung dan TIK. Obat yang biasa digunakan dengan karakteristik tersebut diantaranya adalah labetalol, esmolol dan nikardipin. ${ }^{1,4}$

Pasien perdarahan subaraknoid dengan klasifikasi yang buruk (Klasifikasi Hunt-Hess 4 atau 5) fokus utama tatalaksana tekanan darah adalah untuk menjaga CPP tetap adekuat pada pasien dengan peningkatan TIK. Resusitasi cairan agresif dengan kristaloid isotonik juga diindikasikan untuk meminimalisir hipovolemia akibat natriuresis berat. Nyeri dan agitasi berperan terhadap hipertensi arterial sehingga pasien akan merespons baik terhadap pemberian obat-obatan analgesik dan sedasi. ${ }^{1,4}$
Nimodipine biasanya diberikan pada pasien dengan SAH aneurisma untuk mencegah dan menatalaksana kondisi vasospasme pembuluh darah otak. Nimodipine diberikan untuk mencegah dan meminimalisir terjadinya defisit neurologis akibat iskemik. Namun, pemberian nimodipin dapat menurunkan tekanan darah dengan signifikan terutama pada pemberian secara intravena. Penurunan tekanan darah yang agresif pada pasien dengan SAH harus dipertimbangkan terjadinya risiko iskemik serebral, refleks vasodilatasi akibat obat-obatan, hingga terjadinya peningkatan TIK. Berdasarkan penelitian yang telah dilakukan sebelumnya menunjukkan bahwa nilai CPP $70 \mathrm{mmHg}$ merupakan batas bawah aman minimal pada pasien dengan $\mathrm{SAH} .{ }^{1}$

Kondisi delayed cerebral ischemia (DCI) akibat vasospasme terjadi pada $20-40 \%$ pasien dengan SAH yang berhasil melewati fase inisial perdarahan otak, dan merupakan penyebab kematian utama pada pasien SAH akibat terjadinya kondisi infark. Kondisi DCI diakibatkan oleh terganggunya mekanisme autoregulasi pembuluh darah otak akibat kondisi vasospasme. Gangguan autoregulasi otak ini dapat dideteksi menggunakan alat transcranial doppler dengan melihat perubahan aliran darah otak. Namun tidak semua pasien dengan vasospasme mengakibatkan terjadinya DCI. ${ }^{16}$ Dahulu hampir seluruh institusi kesehatan menggunakan terapi triple $\mathrm{H}$ (hipervolemia, hipertensi, dan hemodilusi) menggunakan pemberian cairan koloid, kristaloid secara agresif dengan target tekanan vena sentral $\geq 8$ atau tekanan diastol pulmonal $>14 \mathrm{mmHg}$, dan dilakukan pemberian obat vasopressor untuk penanganan kondisi pasien dengan SAH. Terapi triple $\mathrm{H}$ awalnya direkomendasikan berdasarkan suatu serial kasus, namun berdasarkan literatur tersebut tidak melaporkan mengenai keamanan penggunaan terapi triple $\mathrm{H}$. Penggunaan terapi triple $\mathrm{H}$ profilaksis pada pasien dengan $\mathrm{SAH}$ aneurisma tidak menurunkan angka kejadian DCI, namun meningkatkan resiko untuk terjadinya kondisi hemodilusi iatrogenic dan memperburuk kondisi jantung. Saat ini banyak klinisi neuroICU menggunakan teknik meningkatkan tekanan darah saja (hipertensi euvolemik) hingga kondisi defisit neurologis telah kembali beresolusi, 
dengan target SBP antara 200-220 mmHg. Teknik hipertensi normovolemia sebaiknya dilakukan di ruang neuroICU dengan menggunakan arterial blood pressure (ABP), kateter vena central, pengukuran kateter arteri pulmonal, pemeriksaan rontgen thoraks berkala, keseimbangan cairan, elektrolit, electrocardiogram (EKG), dan enzim jantung. Obat vasopressor lini pertama yang biasa digunakan adalah phenilefrin, karena pemberian dopamine dan norepinefrin dapat menyebabkan terjaidnya kondisi takikardi. Obat inotropik seperti dobutamine dan milrinone dapat digunakan untuk mempertahankan cardiac index (CI $>4.0 \mathrm{~L} / \mathrm{menit} / \mathrm{m} 2)$ tetap stabil. ${ }^{1,16}$

\section{Stroke Iskemik Akut}

Tingginya kebutuhan metabolisme jaringan otak menyebabkan semakin rentan untuk terjadinya kondisi iskemik otak. Stroke iskemik timbul akibat menurunnya aliran darah ke otak dibawah ambang batas kritis pada suatu daerah jaringan otak yang menyebabkan terjadinya kematian jaringan neuronal. Kondisi iskemik inisial akan menyebabkan terjadinya disfungsi autoregulasi pada daerah sekitar jaringan yang iskemik, bahkan pada hemisfer di sebelahnya. Kondisi stroke iskemik akut, durasi dan lama iskemik akan menentukan hasil luaran pada daerah yang terkena. Terdapat suatu korelasi antara durasi iskemik dengan volume residual aliran darah di otak yang akan memperdarahi jaringan yang telah iskemik, sehingga akan menentukan apakah jaringan tersebut dapat diselamatkan atau akan mati. $^{4,18}$

American Stroke Association (ASA) membuat panduan tatalaksana mengenai penanganan stroke iskemik, namun ASA membuat suatu pernyataan bahwa meskipun arterial hipertensi merupakan penyebab tersering pada pasien stroke iskemik, namun penatalaksanaan yang optimal hingga saat ini masih belum ada, sehingga penatalaksanaanya harus berdasarkan kondisi pasien. Rekomendasi oleh AHA menyarankan untuk menahan pemberian obat antihipertensi kecuali jika akan dilakukan tindakan trombolisis terencana, dan terbukti adanya kerusakan organ non-serebral akibat hipertensi atau tekanan darah pasien sangat tinggi ( $\mathrm{SBP}>220 \mathrm{mmHg}$ dan $\mathrm{DBP}>120$
$\mathrm{mmHg}$ ). Namun, hingga saat ini pemberian obat antihipertensi, target tekanan darah yang aman masih merupakan hal yang kontroversial. ${ }^{1,4,11}$

Saat kita memutuskan untuk memberikan terapi antihipertensi pada pasien dengan stroke iskemik, maka sebaiknya diberikan pemberian obat antihipertensi intravena yang mudah untuk dititrasi, diantaranya adalah nikardipin, labetalol, esmolol, atau enalaprilat. Indikasi memberikan obat antihipertensi pada pasien yang akan dilakukan trombolisis adalah karena tekanan darah yang tinggi akan meningkatkan resiko untuk terjadinya ICH. Target tekanan darah pada pasien yang akan dilakukan terapi trombolitik adalah $\mathrm{SBP}<185 \mathrm{mmHg}$, dan $\mathrm{DBP}<110 \mathrm{mmHg}$. Agen obat antihipertensi intravena yang biasa digunakan untuk menurunkan tekanan darah pada pasien yang akan dilakukan terapi trombolitik adalah labetalol, enalaprilat, dan nikardipin. Pasien yang telah dilakukan terapi trombolitik sebaiknya SBP dipertahankan $<180 \mathrm{mmHg}$, dan DBP $<105$ mmHg dalam 24 jam berikutnya. ${ }^{1,4}$

Sebagian besar $(80 \%)$ pasien dengan iskemik serebral akan terjadi kondisi peningkatan tekanan darah akut terlepas dari subtipe etiologi atau komorbid hipertensi sebelumnya. Namun, tekanan darah secara spontan akan menurun perlahan setiap waktunya selama 7-10 hari, hal ini merupakan suatu respons kompensasi tubuh untuk menjaga dan meningkatkan CPP dan CBF pada daerah penumbra iskemik. Daerah penumbra iskemik akan timbul hingga 3-6 jam setelah onset iskemia, dan memiliki peranan penting terhadap terjadinya kerusakan sel. Iskemik serebral akan mengganggu autoregulasi dan dapat menimbulkan kondisi fokal pressure-passive $\mathrm{CBF}$, dimana kondisi tersebut akan diperberat oleh penurunan tekanan darah menggunakan obat-obatan farmakologis. Mekanisme lain yang menyebabkan terjadinya peningkatan tekanan darah pada pasien stroke iskemik adalah stres, nyeri, mual, retensi urine, dan meningkatnya TIK. ${ }^{1,4,11}$ Hingga saat ini masih belum jelas apakah kondisi hipertensi akut menyebabkan peningkatan angka mortalitas dan morbiditas pasien stroke. Beberapa penelitian yang telah dilakukan menunjukkan hasil yang saling berlawanan terkait dengan hal tersebut, 
diantaranya menyatakan bahwa penurunan tekanan darah tiba-tiba pada 4-48 jam pertama setelah stroke berkaitan dengan luaran yang baik, namun penelitian lainnya menunjukkan hasil luaran yang buruk. ${ }^{1}$

\section{Cedera Otak Traumatik (COT)}

Hipertensi lebih jarang terjadi dibandingkan dengan kondisi hipotensi pada pasien trauma karena beberapa alasan yakni eksanguinasi, vasodilatasi akibat mekanisme neurogenik/ respons inflamasi sistemik, pneumothoraks, dan neurogenic stunned myocardium. Berdasarkan penelitian yang dilakukan oleh study of treatment of acute hypertension (STAT) mendapatkan bahwa dari 432 pasien dengan gangguan neurologis, hanya $8 \%$ pasien yang mengalami kondisi hipertensi akut dengan COT. Namun kondisi hipotensi akut merupakan faktor utama yang diasosiasikan dengan hasil luaran yang buruk pada pasien COT. Saat ini penatalaksanaan diutamakan pada protokol resusitasi secara intensif pada tekanan darah atau CPP. Tujuan utama tindakan resusitasi adalah untuk mengoptimalkan cardiac output, CBF dan perfusi jaringan otak untuk mencegah cedera otak iskemik sekunder. ${ }^{1}$

Tatalaksana COT derajat berat pada era sebelumnya bertujuan untuk menurunkan TIK dan edema otak. Saat ini tatalaksana pasien COT dilakukan berdasarkan 2 hal, yakni terapi menargetkan nilai CPP (Rossner approach) dan menurunkan volume intrakranial. Strategi pertama dilakukan dengan mempertahankan level CPP tetap tinggi pada kondisi stres kardiopulmonal. Luaran pasien dengan strategi tersebut ternyata baik. Hingga saat ini meskipun telah banyak panduan tatalaksana mengenai regulasi tekanan darah dan CPP pada pasien COT, belum ada satu rekomendasi yang telah disetujui oleh seluruh ahli di dunia ini, namun hampir seluruh rekomendasi menyarankan untuk menjaga $\mathrm{CPP}>70 \mathrm{mmHg}$ walaupun harus menggunakan obat vasoaktif. Strategi meningkatkan CPP hingga batas yang cukup tinggi memberikan hasil yang baik dalam menurunkan TIK dan memberikan hasil luaran yang lebih baik dibandingkan penggunaan strategi penurunan TIK konvensional. Namun, berdasarkan penelitian lainnya menyatakan bahwa tidak terdapat perbedaan hasil luaran yang signifikan antara kelompok CPP tinggi dengan teknik penurunan TIK konvensional, tetapi angka kejadian acute respiratory distress syndrome (ARDS) lebih besar pada kelompok CPP yang tinggi. Berdasarkan penelitian lain mendapatkan hasil bahwa nilai CPP yang lebih rendah (nilai batas bawah CPP dibawah $70 \mathrm{mmHg}$ ) memberikan hasil luaran yang lebih baik karena menurunkan kejadian acute respiratory distress syndrome (ARDS) dan kebutuhan obat vasoaktif yang lebih rendah. ${ }^{1,19}$

Obat yang biasa digunakan untuk meningkatkan CPP diantaranya adalah obat-obatan golongan vasoaktif seperti norepinephrine, phenylefrin, atau dopamine. Data/penelitian mengenai obat mana yang lebih baik untuk meningkatkan CPP hingga saat ini masih belum banyak. Suatu penelitian yang membandingkan antara obatobat vasoaktif ini dalam meningkatkan CPP, mendapatkan bahwa norepinephrine memiliki efek yang lebih dapat diprediksi, dan konsisten terhadap CPP, sedangkan dopamine didapatkan memiliki pengaruh terhadap peningkatan TIK. Berdasarkan beberapa penelitian lainnya mendapatkan bahwa penggunaan phenylephrine lebih superior dibandingkan norepinephrine dan dopamine. ${ }^{1,19}$

Berdasarkan panduan tatalaksana yang dikeluarkan oleh brain trauma foundation (BTF) edisi ke-4 dikatakan bahwa pada pasien dengan usia antara 50-69 tahun sebaiknya SBP dipertahankan $\geq 100 \mathrm{mmHg}$, sedangkan pada pasien dengan usia 15-49 tahun atau $>70$ tahun, sebaiknya SBP dipertahankan $\geq 110 \mathrm{mmHg}$ untuk menurunkan angka mortalitas dan meningkatkan hasil luaran. Rekomendasi untuk menjaga CPP antara 60-70 hingga saat ini masih belum disarankan karena bukti penelitian yang masih sedikit, namun dapat digunakan bergantung pada kondisi autoregulasi pasien. Hindari penggunaan obat vasoaktif dan pemberian cairan yang agresif untuk mencapai $\mathrm{CPP}>70 \mathrm{mmHg}$ karena dapat menyebabkan terjadinya hiperemia dan kejadian ARDS. ${ }^{19}$ Berdasarkan panduan tatalaksana yang dikeluarkan oleh Lund (Lund 
concept) mengatakan bahwa lebih bijaksana dalam penggunaan obat antihipertensi untuk meminimalisasi tekanan hidrostatik intravaskular dan volume darah serebral. Lund concept berasumsi pada pasien dengan COT berat terjadi suatu kondisi kerusakan sawar darah otak, dan merekomendasikan tindakan manipulasi untuk menurunkan tekanan hidrostatik dan meningkatkan tekanan osmotikuntuk menurunkan volume darah otak dan edema vasogenik. Hal tersebut dilakukan dengan menjaga nilai CPP $50-70 \mathrm{mmHg}$ namun tetap memastikan kondisi euvolemik dengan kadar hemoglobin, $\mathrm{PCO}_{2}$, protein plasma pada nilai normal. ${ }^{1}$ Monitoring multimodal terhadap fungsi otak invasif seperti monitoring CBF, tekanan oksigen jaringan otak, saturasi oksigen vena jugularis (jugular bulb), dan mikrodialisis memberikan manfaat yang baik dalam melakukan strategi terapi pasien dengan COT berat. ${ }^{1}$

\section{Spinal Cord Injury (SCI)}

Prinsip tatalaksana pasien dengan SCI adalah melakukan tindakan dekompresi dini dan stabilisasi, untuk mencegah terjadinya cedera sekunder akibat cedera inisial. Beberapa strategi secara rutin telah dilakukan untuk mencegah terjadinya cedera sekunder, diantaranya adalah menjaga tekanan darah dengan menggunakan terapi cairan dan obat vasoaktif, terapi hipothermia, terapi untuk menekan respons inflamasi, dan terapi lainnya. Terdapat suatu rekomendasi panduan tatalaksana yang dikeluarkan oleh American Association of Neurological Surgeons/Congress of Neurological Surgeons (AANS/CNS) menyarankan untuk mengkoreksi kondisi hipotensi dengan target MAP $85-90 \mathrm{mmHg}$ selama 7 hari pascakejadian SCI. Protokol tersebut telah digunakan oleh beberapa penelitian, dan menunjukkan hasil luaran yang signifikan. Berdasarkan literatur ini menyarankan penggunaan norepinephrine dan phenylephrine sebagai terapi lini pertama untuk terapi menggunakan vasoaktif pada pasien cedera vertebra cervical dan vertebra thorakalis atas. ${ }^{20}$

Penanganan tekanan darah pada pasien dengan SCI akut tidak sekompleks penanganan tekanan darah pada pasien COT, walaupun spinal cord memiliki mekanisme autoregulasi yang hampir sama dengan otak. Hipotensi pascatrauma SCI merupakan hal yang sering terjadi, hal tersebut dapat terjadi akibat kondisi hipovolemia karena polytrauma, atau akibat efek trauma langsung pada daerah cervical atau thorakalis yang menyebabkan terjadinya syok neurogenic. Syok neurogenik pada pasien dengan SCI diakibatkan oleh penghambatan akut tonus vasomotor simpatetik perifer karena gangguan kontrol supraspinal, atau karena suatu kondisi sistem parasimpatis yang intak melalui saraf vagus, sehingga menyebabkan terjadinya ketidakseimbangan sistem saraf otonom (terjadi kondisi penurunan tonus pembuluh darah dan bradikardia). Kondisi gangguan tekanan darah yang dapat timbul pada pasien dengan SCI lainnya adalah disrefleksia anatomis. Kondisi ini merupakan suatu keadaan dimana tekanan darah menjadi labil dan kondisi hipertensi ekstrem dapat timbul akibat stimulasi fisik minor dibawah level cedera). ${ }^{1}$

\section{Simpulan}

Peningkatan atau penurunan tekanan darah yang ekstrem pada kondisi cedera otak atau cedera tulang belakang dapat menyebabkan terjadinya suatu cedera sekunder, dimana akan meningkatkan angka mortalitas dan morbiditas pada pasien. Hubungan kausal antara tekanan darah ekstrem dan cedera otak masih diperdebatkan. Deteksi kelainan autoregulasi yang terjadi setelah cedera otak dan tulang belakang perlu dilakukan sebagai acuan untuk melakukan terapi kontrol tekanan darah yang optimal, dan menghindari komplikasi akibat penurunan atau peningkatan tekanan darah yang berlebihan

\section{Daftar Pustaka}

1. Layon AJ, Gabrielli A, Friedman WA. Textbook of neurointensive care, 2nd ed. Springer. 2014;12 241-52.

2. Parida S, Badhe A. Emergence hypertension in patients undergoing intracranial surgery. The Internet Journal of Anaesthesiology. 2008;22(1):1-5 
3. Hoxha A, Demneri M, Pilika K, Gjini O, Filipi $\mathrm{N}$, Saraci M, dkk. Postoperative hypertension after craniotomy and cathecolamine secretion. European Journal of Anaesthesiology. 2005; 22:84.

4. Pancioli AM, Kasner SE. Hypertension management in acute neovascular emergencies. Emergency Medicine Cardiac Research and Education Group. 2006; 3:1-13

5. Varon J, Marik PE. Perioperative hypertension management. Vascular Health and Risk Management. 2008; 4(3):615-27.

6. Basali A, Mascha EJ, Kalfas L, Schubert A. Relation between perioperative hypertension and intracranial haemorrhage after craniotomy. Anesthesiology. 2000;93:48-54.

7. Siquera EMP, Diccini S. Postoperative complications in elective and nonelective neurosurgery. Acta Paul Enferm. 2017;30(1):101-8.

8. Marik PE, Varon J. Hypertensive crisis: challenges and management. Chest 2007;131: 1949-62.

9. Salkic S, Mujanovic OB, Ljuca F, Brkic S. Clinical presentation of hypertensive crises in emergency medical services. Mater Sociomed. 2014; 26(1): 12-6.

10. Parker E. Co-management of hypertension in the neurosurgical patient for the hospitalist. Proceedings of UCLA Healthcare. 2015; 19:1-2.

11. Zaidi G, Chichra A, Weitzen M, Narasimhan M. Blood preesure control in neurological ICU patients: what is too high and what is too low?. The Open Critical Care Medicine Journal. 2013;6(supp11):46-55.

12. Cline DM, Amin A. Drug Treatment for hypertensive emergencies: new concepts and emerging technologies for emergency physicians. Emergency Medicine Cardiac
Research and Education Group. 2008;1:1-12.

13. Antihypertensive Treatment of Acute Cerebral Hemorrhage (ATACH) investigators. Antihypertensive treatment of acute cerebral hemorrhage. Critical care medicine. 2010; 38(2):1-21.

14. Steiner T, Salman RA, Beer R, Christensen $\mathrm{H}$, Cordonnier C, Csiba L,dkk. European stroke organisation (ESO) guidelines for the management of spontaneous intracerebral haemorrhage. World Stroke Organisation. 2014; 1-16.

15. Hong D, Stradling D, Dastur CK, Akbari Y, Groysman L, Al-Khoury L, dkk. Resistant hypertension after hypertensive intracerebral haemorrhage is associated with more medical interventions and longer hospital stays without affecting outcome. Frontiers in Neurology. 2017;8(184):1-7.

16. Dority JS, Oldham JS. Subarachnoid haemorrhage. Anethesiology Clinical. 2016; 34:577-600.

17. Grasso G, Alafaci C, Macdonald L. Management of aneurysmal subarachnoid hemorrhage: state of the art and future perspective. Surgical Neurology International. $\quad 2017 ; \quad 8(11): 1-10$.

18. Jordan JD, Powers WJ. Cerebral autoregulation and acute ischemic stroke. American Journal of Hypertension. 2012; 25(9): 946-50.

19. Dash HH, Chavali S. Management of traumatic brain injury patients. Korean Journal Anesthesiology. 2018; 71(1):12-21.

20. Saaedeh YS, Smith BW, Joseph JR, Jaffer SY, Buckingham MJ, Oppenlander ME, dkk. The impact of blood pressure management after spinal cord injury: a systematic review of the literature. Neurosurgery Focus.2017;43(5):1-7. 